\title{
PROBLEM IN IDENTITY, POSTMODERNISM, AND ERICH FROMM
}

\author{
Ian Raymond B. Pacquing \\ Philosophy Department, University of Santo Tomas \\ Philippines
}

\begin{abstract}
This paper argues that identity which is the locus of emotional and social phenomena of an individual becomes problematic particularly in postmodern society. Postmodern society calls for a socio-cultural and epistemological revolution which permeates the very core of our social existence. Coupled with the immensity and massive effects of the market industry, postmodern culture affects our lives through the dissolutions of boundaries, geographies, and our ethnicities so that our sense of personal and social identity is left into perpetual disintegration, struggles and contradictions. The so-called "inner" and "outer" community which we once cherished inevitably dissolved into the arena of the market industry. Consequently, the sense of "I-am" which Fromm considers as an existential human need already deeply roots itself towards commodity fixations rather than in our group or in our ethnic communal relationships. It is in these contexts that this paper contends a necessity to redeem identity not only as a psychological base but more of an existential human need. Further, this paper maintains that Fromm's notion of relatedness and rootedness are necessary elements in identity formation since they serve as the existential psychic cores that lead towards being truly at home amidst a fragmented social world.
\end{abstract}

\section{NT RODUCTION}

This paper is divided into three parts. The introductory part deals with the nature of identity from the lens of a Frommian framework. This is supported by several authors whose ideas support the psychoanalytic thoughts of Fromm. The second part discusses how the problem of identity becomes an existential concern in the postmodern world. Amidst the rise of consumerism, technological advances, and the impact of the global market, the self becomes fluid and thus inner contradictions happen. The last part is an attempt on my part to reclaim this disintegrated and fabricated sense of self. Here, the 
psychoanalytic schisms between the human and the non-human in us are discussed. Amidst the immensity of the social forces, I want to show that psychoanalytically, there is an imperative need to unite. This is where relatedness and rootedness become existential need in encountering the self, others, and the world.

\section{A SENSE OF “I-AM"}

Let us clarify first what identity is at least in the Frommian sense. Identity is the awareness of oneself as a separate entity. It is the feeling of "I-am-I"; i.e., the capacity to make decisions, awareness of this capacity to effect change within oneself, cognizance of other people as different persons, and awareness of those decisions as effects of one's actions (Erich Fromm, 1955, 59-60). This sense of identity, according to Fromm, emerges from the "primary bond" that ties the infant from the mother and nature. $\mathrm{He}$ continues: "the infant, still feeling one with the mother, cannot yet say 'I', nor has he any need for it. Only after he has conceived of the outer world as separate and different from himself does he come to the awareness of himself as a distinct being, and one of the last words he learns to use is 'I', in reference to himself' (Fromm, 1955, 60). Rainier Funk (1982, 61-65), who is Fromm's literary executor, agreeably explains that having identity means having to feel the unity in oneself with nature and surrounding environment. As a matter of fact, we can connect this feeling of unity with the assertion of another noted psychologist by the name of Margaret Mahler. Mahler (1975, 223-224) contends that identity is the awareness of self-constancy as one engages himself or herself in the world. Unity and self-constancy resonate too in Jeff Noonan's $(2003,5)$ commentary on postmodernity. He $(2003,5)$ commented that having identity is the experience of the "I" as a self-determining subject; i.e., an active force in the order of things. This 'I' as a self-determining subject, argues Robert Dunn $(1998,32)$, allows the individual to acquire the capacity towards self-consciousness; i.e., to determine actions through one's conscious activity as an individual. These assertions of Dunn and Noonan support what Fromm opines earlier that identity is the consciousness of being a separate and distinct entity. In its encounters with the outside world, identity becomes alive; i.e., the active renewal of oneself to grow, flow out, love, and become (Fromm, 1997, 72). Peter Zima $(2015,4)$ repeats these same sentiments of Fromm in relocating the role of the individual in the modern times. Identity, for him, is the aspiration to become the instrument of one's will and not of other men's acts of the will. This also rings in Leonidas Donskis $(2009,7)$ when he expresses that "Nobody will ever be able to define me, and only I, myself, can assume responsibility for my identity and handle it - this is precisely where the essence of my personal autonomy, freedom, vulnerability, and even curse, if you will, lies." Fromm $(1955,60)$ then asks "How do I know that I am I?"

This is the question which was raised, in a philosophical form, by Descartes. He answered the quest for identity by saying, "I doubthence I think, I think - hence I am." This answer put all the emphasis on the experience of "I" as the subject of any thinking activity, and 
failed to see that the "I" is experienced also in the process of feeling and creative action.

Hence, this act of experiencing the "I" is an expression of the self. This understanding rises to an existential domain from which one's own experience "imparts a much greater sense of urgency, clarity and resolve" (Burston 2006, 119-130). Having an identity then is not only a natural experience of the self but an existential expression of my own understanding of my own position within a social network as a unique individual (Zima $2015,11)$. Being sympathetic to one's position along the social sphere is the reacclamation of my own narrative in the course of history. It is my exclusive rights as a storyteller, a symbolic transmission belt that bridges my past, present and future through the transmission of tradition.

\section{Identity in the Postmodern World}

Why then is identity a postmodern concern? With the rise of postmodern culture, contemporary society turns into a highly accentuated environment with the rise of consumerism, technological and scientific advances, and the embedding of hypercapitalist constructs. Consequently, there is the rapid expansion of mass media, the urbanization of the countryside, and the standardization of life through mass consumption. These fundamental social changes call for epistemological and political responses which inject the question of identity as the core of postmodern concerns (Dunn 1998, 2). Since we now have to engage our lives through digital and technological alterations, our specific responses call for particular movements, styles, moods, or representations that reflect these social developments in the postmodern world (Dunn $1998,2)$. These social advances, as Berman $(1982,15)$ noted it well, cut across all boundaries, geographies, and ethnicities. Accordingly, life becomes so compressed and this was stressed accordingly by the well-known sociologist Zygmunt Baumann. Baumann (2001, 3-5) underscores the point that the fast social changes occurring within our midst loosen the boundaries between the "inside" and the "outside" of our sense of community where identity formation is supposed to take place. As a matter of fact, the rapidity of change in our postmodern society disallows us to discuss substantially of traditional places where personal and social identities are embedded since those routinized social practices which substantially connect the past, present, and an imagined future are cancelled (Bauman 2001, 12-18).

Consequently, this leads to, as Dunn $(1998,32-33)$ argues, the fluidity of the self, i.e., a self that now exhibits normative patterning yet simultaneously existing in a state of flux through social adaptation. More than this, Marshall Berman $(1982,15)$ points out that this fluidity of the self leaves us all into perpetual disintegration, struggles, and contradictions. As a result then, there is no stability of the self, no identity to speak of since the boundary that delineates one's community from the other is lost. According to Jaber Gubrium $(1995,555)$, postmodern thinking would just settle and features the self as constantly changing, ephemeral, liquid, decentered subject which is always being tossed by social forces outside its control. In this case, says Panfilova $(2010,14)$, one's 
psychic energy is deprived of its human base. This deprivation, as Fromm $(1955,59)$ would argue, dislodges the individual of the capacity to speak for oneself as a separate entity, as a distinct individual who could actually express "I-am-I." Instead of engaging meaningfully towards ethnic groups and communal relations in order for our personal and social identities to thrive, postmodern culture sways one's psychic energy towards commodity fixations (Dunn 1998, 66). Therefore, the pulsations of life, its own tremors, and unpredictable movements, argues Biancoli (2006, 4-5), which make it alive and meaningful are now transformed into storehouse of facts, events, and possessions. What is stored in us is a globalized culture where ethnic and communal differences are obliterated (Panfilova 2010, 43-51). In this sense then, says John Hewitt (1989, 5-6) our instinctual drives have become "other-directed" rather than "inner directed". In other words, in the postmodern environment, Fromm $(1955,61)$ laments that individual agency turns into status identification or herd identity where one can only sense a self as it unquestionably belongs to the crowd. Dunn echoes Fromm in this sense. Dunn (1998, 167) explains that our traditional or conventionalized and institutionalized roles are weakened and have been replaced by more individualized and "fluid" lifestyles. Further, Pacquing $(2017,136)$ states too that our inner world is reordered into the demands of postmodern environment just as the laws of the market replace our non-commodified values. Fromm clearly expresses this thinking in To Have or To Be (1976). Fromm (1976, 87) elucidates that with these kinds of social arrangements, the ' $I$ ' is thus transformed into things since our relational experiences with the other revolves around the principles of acquisition, profit, and property, which produce a social character oriented around having. So, Fromm (1959, 31-36) illustrates that the self sees the world through a reified discursive system of thinking; i.e., we are transformed into things where we are dissected and manipulated at the expense of profit. Even Stephen Frosh (1991, 6-7) supports this position of Fromm when he says that what is now mirrored internally are the fluid, fast changing tumultuous contours of a postmodern set-up; and consequently, nothing holds our very existential 'I' ' but to slip away leaving it empty. This emptiness, Peters $(2016,3)$ declares, 'silences' the context in which this very 'I' lives and reduces us into atoms that do not bond with others or nature. In this context, our very ' $\mathrm{I}$ ' is transformed into an illusion making us believe that we are unique and free while manipulating its existence on a minute scale (Peters 2016,7).

Consequently, there is nothing to anchor our aspirations and dreams and everything including the self turns into spilling and thrilling leaving us into empty spaces (Frosh 1991, 6-7). Since the 'Í' is beholden to nobody, Pacquing $(2017,137)$ argues that our life now becomes a matter of consumerist pleasure, solipsist jouissance that fosters even further a relation of having that dominates and controls the inner self. Psycho-socially, our materialist environment has become an intolerable human habitat since we are now deprived of our usual base of socialization from which we perceive a loss of personal and social identity (Panfilova 2010,2). These distressing social forces cut and separate us from our home base. Our instinctual ability to relate humanely to the other and to the world, Funk $(2013,8)$ comments, is now turned into the pleasures of materialist environment. Withdrawn from a humane atmosphere, we are thrown into 
tremendous insecurity and helplessness which push us further to substitute our sense of identity with a pseudo-self, which is the sum total of expectations others have about me (Fromm 1944, 382). Funk $(2010,86)$ acknowledges this Frommian position. He argues that the loss of identity drives us all by our ego-oriented machinery. Here we reconstruct our world without any limitation, without any boundaries, without any ontological base, as long as the structures of life suit the locus of "I-am-me" orientation. Because of this, Fromm $(1964,39)$ further says that there is no relation, not even a sense of commitment. Everything is arbitrarily reconstructed making a narcissistic self as its center. The go-between of our social, political, and cultural milieu is this same self grounded on its very capacity to see itself and the world in relation to having. Normative discourses make sense only if it satiates this "me-mentality" which now inflates its ego ideal. Indeed, postmodern society, as George Ritzer (2002, 20-25) explains, shoves us towards the irrationality of our rationality as human beings. And this is best described in the words of Lasch $(1979,49)$ when he asserts that the loss of identity pushes us into a war of all against all. Perhaps the reason for this is expressed accordingly by Frie (2003, 855-968) who laments that our postmodern environment instills an inauthentic core; i.e., a self which is always dependent upon social constructivism from which other possibly relative self-construction occurs at any particular time. Hence, the self becomes fractured in a decentered environment; and this would entail all agential experiences opaque (Burston 2006, 119-130). In other words, our postmodern society does not recognize the fact that the capacity to organize and experience all actions is still dependent upon the individual person for whom that precise experience takes place and for whom his/her choices do have actual or potential consequences (see Burston 2006, 119).

\section{EXISTENTIAL DICHOTOMIES AND THE EXISTENTIAL NEEDS FOR RELATEDNESS AND ROOTEDNESS}

Hence, I argue in this paper that the issue of identity has turned into an existential concern. Our existential "I" wanes and there is nothing to hold on to except that relative self-construction enunciated by our postmodern environment. At this point then, I maintain further that there is a need to regain a sense of identity since the degree from which an individual can express himself depends only upon his awareness of himself as a separate self (Fromm 1955, 57). From a psychoanalytic perspective persons, as individual agents, must emerged from their fixations from nature, from their clan or group. Fromm $(1955,60)$ says there is a need to transcend in order for the individual to say "I-am"; i.e., to put emphasis on the 'I' as subject of any thinking activity. However, this ' $\mathrm{I}$ ' is not an abstract one. It is embedded in particular situations. That in the process of assimilating and adapting to the concrete social conditions, any individual remains as agent of his/her own will, crafting pictures of himself/herself through different social orientations. These frames of orientations, Fromm $(2013,2)$ explains, make it possible for us to make consistent decisions for our growth and development. In this sense, Biancoli (1995,3-4) describes this Frommian position well. He explains, our social 
82 IAN RAYMOND B. PACQUING

dispositions move us to enter into "center-to-center" relationships. These communal unions speak of our existential need to overcome our separations with nature. It is, according to Fromm $(1955,26)$, a matter of existential dichotomies the solution of which is to enter into new relationships with the other and to the world. To get a better understanding of these, let me first explicate Fromm's notion of existential dichotomies.

\section{Existential Dichotomies}

Fromm $(1957,6-7)$ elucidates that human nature is a tossed between animality and non-animality, between life and death, between the awareness that man is born yet he is going to die, and between the fact that every individual lives a life like all other animals and the fact that he/she also wants to transcend his/her own sense of animality. This dichotomy either pulls us forward or backward in life. Either we progress and advance forward in history or we regress back to animal form of existence; i.e., just like any other animal, we experience static incapacity to live life to the fullest. This is the reason why, declares Fromm, in The Sane Society, that "When man is born, the human race as well as the individual, he is thrown out of a situation which was definite, as definite as the instincts, into a situation which is indefinite, uncertain and open" $(1955,24)$. Fromm used the allegory of the biblical story of Adam and Eve to describe this existential paradox. He says that we follow physiologically the dictates of our instincts just like what other creatures do. We eat, drink, sleep, and rest following the natural flow of our animal stature. For him, we are basically animals in paradise. We do not yet possess any reason to know and to understand ourselves and our environment. We do not even know, as we are with other creatures, that we are primarily human beings. We are just one among the many creatures God created. Our instinctive acts are solely for our own survival. However, when Adam and Eve ate the forbidden fruit, for the first time, humans starts to become aware. We begin to possess reason, and our intelligence surpasses that of other creatures. It is here that history begins to unfold. Human beings had cut its ties with nature which made them a "part of the soil of his tribe." With this situation, Fromm (1957, 6-7) asserts we are left alone, separate, and helpless. Free but alone, our lives become an unbearable prison which might lead to insanity if we could not liberate ourselves, unite ourselves and reach out in some form or another with men and with the outside world. In fact, he $(1957,23)$ stresses, that "man is the only animal who finds his own existence a problem which he has to solve and from which he cannot escape." Hence, Fromm $(1955,25)$ contends that there should be an "understanding of man's psyche [which] must be based on the analysis of man's needs stemming from the conditions of his existence." As a matter of fact, life is a process of rebirth, but each state of being born is so frightening that either we regress to the original oneness with nature or move forward in history. He $(1955,26)$ argues:

But at any new step, at any new stage of our birth, we are afraid again. We are never free from two conflicting tendencies: one to emerge from the womb, from the animal form of existence into a more human existence, from bondage to freedom; another, to return to the womb, to nature, to certainty and security. 


\section{The existential need towards relatedness and rootedness}

Any attempt to return to animality is too painful and any step forward in history is frightening too. However, we can never rest by just adapting passively to nature since our most intensive passion and needs are rooted in the very peculiarity of our existence (Fromm 1955, 27). We need to find an inner equilibrium just to satisfy not only our instinctual and physiological needs. More than these, we ought to satisfy our human needs without which we become insane (Fromm 1955, 27; 1957, 7). Through reason, maintains Fromm, we become aware of our own separateness and individuation. Yet, we could not bear this awareness if we just remain passive. We need to move forward. This thought was also expressed by Mclaughlin $(2001,276)$ who opines that in our inner life, there exists a passionate striving to overcome this existential problem. Even Risari $(2017,1)$ rejoins and comments that deep within the individual lies a striving which speaks of our most inner voice arising from our most inner depth. This voice pushes us to move forward and form new ties with his fellow men. Fromm $(1955,29)$ then claims:

The necessity to unite with other living beings, to be related to them, is an imperative need on the fulfillment of which man's sanity depends. This need is behind all phenomena which constitute the whole gamut of intimate human relations, of all passions which are called love in the broadest sense of the word.

Therefore, Funk $(1982,21)$ explaining this Frommian existential dichotomy, notes that the necessity to unite; i.e., to be related to others and to the world defines our fundamental existential needs as human beings. It stems from the fact that we are primarily social beings and as such our relatedness to ourselves and to others becomes an essential aspect of becoming human (Fromm 1941, 249). Funk $(1982,60)$ further expounds this and argues that "just as the physiological need, hunger, causes death if not satisfied, so intellectually and spiritually healthy human life is possible only where the specifically human need for relatedness is responded to. Without this response, says Fromm, man becomes psychotic. Our lives then must be expended in a form of communal sharing in order to experience human solidarity with others (Fromm 1955, 30). Clarifying this thesis, Lankshear $(2003,57)$ explains that it is a human need to establish a "new unity" with fellow beings and nature. Therefore, it is through human relatedness that we come to transcend this existential paradox. However, Fromm warns us thouh that forming new unities does not mean to dominate the other or to submit ourselves unto the demands of the other. This, according to Fromm, $(1955,29)$ is the sado-masochist attitude where the symbiotic union of both individuals has lost its integrity and freedom. Both "live on each other and from each other, yet suffer inner strength and self-reliance..." (Fromm 1955, 29). Both, although consciously related, are dependent from each other without which one cannot exist. Thus, forming new unities with the other must be based on what Fromm mentions earlier as "center-to-center" relationship where we feel as "responsible for their well-being as for our own" (Biancoli 2002, 589). This responsibility rests on one passion called love (Fromm 1955; 1957). To be related then is to find union 
with somebody yet retaining the separateness and integrity of the self. To be related is to enter into communion with the other which permits the unfolding of the inner self (Fromm 1955, 30). Only then our common humanity finds its completion when we come to relate with other human beings, rooted with them from whom one's fulfillment and happiness rest (Fromm 1947, 14). But what does Fromm mean by existential rootedness?

As we move forward in history, but standing and being left alone without any existential roots is more frightening according to Fromm. He $(1955,37)$ explains that "if man loses his natural roots, where is he and who is he? He would stand alone, without a home; without roots; he could not bear the isolation and helplessness of this position." Hence, to be in relation with other beings is to be also rooted in communion with them. Unity with others, Fromm $(1955,38)$ opines, is to find once again our human roots and only then that we can share a new human home. With the perplexities in our postmodern societies, we are thrown into situations where we remain helpless. We are carried into a situation where our socialization is deprived of its human base. There is a need then to enter into new relationships rooted on the common humanity that we all share. He (1964, 49) asserts: "This humanist experience is fully possible only if we enlarge our sphere of awareness. Our own awareness is usually confined to what the society of which we are members permits us to be aware." But the individual is more than what society demands. The individual is primarily human. In his book On Being Human, he explicitly describes his humanistic position. He (1999, 10-12) says

This humanistic experience consists in the feeling that nothing human is alien to one, that "I am you", that one can understand another human being because both of us share as our common possession the same elements of human existence...the broadening of self awareness that humanistic experience brings about-including as it does the transcending of consciousness and the revelation of the sphere of the social unconscious- enables man to experience himself in the full dimension of his shared humanity.

It is in forming new relationships and rooting ourselves in the common ground which is humanity that new identities arise. Nonetheless, Meyer $(2006,3-6)$ comments on this Frommian exposition and argues that in spite of the standardization of postmodern society, there are many positive stances where personal and social identities develop. Notwithstanding the deconstruction of overarching cultural patterns, postmodern society reconstructs itself to becoming freer. It also gears towards openness to new systems of relations. In this sense, more vistas and opportunities are given to us who could put emphasis on our own identity and autonomy as a human being. Through this, we need to form a concept of ourselves because we are not lived, but live. In fact, Fromm mentions that through those pluralities of human experiences, those diversities of our social situatedness, each of us is not statically passive but continuously giving birth unto our own lives (see Davis 2003, 839). Fromm again indicates in The Fear of Freedom $(1941,10)$, and in To Have or To Be $(1997,53)$, that we are not static beings that observe our environment from a distance; rather we are participative beings that continuously 
allow life to flow and give birth to new forms of experiences. Through these multifarious experiences, we can foster our self-esteem, which is our own sense of "I-am." Remarking again on Fromm's notion of relationship, Meyer $(2006,62)$ adds that postmodern setting offers "new kinds of freedom [emerge] that allow personal self-realization and to live authentically. These new freedoms can be described as liberation from repressive traditions, norms and rules, from hierarchies and obligations, from mechanisms of suppression, repression, and disavowal." $\mathrm{He}(2006,2)$ added too that with these new freedoms, new spaces for innovations, new visions, and new adaptations could then enhance more autonomies and relationships.

Banking on these arguments, Funk $(2010,86)$ likewise says that the openness of postmodern society moves us towards self-determination, one that is not limited by guidelines or requirements. He $(2013,2)$ added further that "new forms of togetherness are created in the interpersonal space and in the social structure, that measure up to this wish for self-determination." In addition, he says that through our digital technology, our surrounding reality can be newly and differently developed and perceived in a new way (Funk 2013). This new union with fellow men then allows space and time to open new horizons so that relating to the other as other becomes so essential in reconstructing the individual sense of reality from which "we contribute to the experience and are not merely recipients of experience" (Davis 2003, 3). With our active participation with the other, our unboundedness in a postmodern setting begins to shed light. Through our openness to and with the other, we begin to see our similarities and differences (Chen 2014). In this sense, we move dialectically with the other while at the same time retaining our separateness and self-integrity (Fromm 1955, 30).

Interpersonal fusion then is the most powerful striving in man. It is the force, says Fromm $(1957,14)$, that keeps the human race, society, clan, or family together. It is forming new identities through communal relationships that we give ourselves to the other, enriching the other, enhancing the aliveness of the other by increasing one sense of aliveness in one's self (Fromm 1957, 14). In fact, Fromm $(1992,17)$ clarifies that "the most important elements of the psychic structure are the 'attitude' of the individual to others or to himself, or, as we should like to say, the basic human relation, and the fears and impulses which, in part directly, in part indirectly, arise out of this behavior." Hence, through relatedness and rootedness as existential needs, it is essential for us to reach out, gives to, and receives from one another; and by doing this, we create meaning to our world (see Frederickson 2005, 81). In this sense, Fromm (1955, 35-36) once again remarks, that through our relatedness and rootedness, we create life; i.e., a miraculous quality that we all share with others because through creation, we become active agents in history. Fromm is echoed too by Frederickson's $(2005,80)$ acknowledgment that through creating life, we account for "forces of determinism while acknowledging the role of freedom, the critical factor necessary for any relating." Our social discourse becomes the immediate locus of my existential experience (see Zima 2015, 12). The social narrative makes me who "I am."

Nevertheless, it must be noted though that the discursive space which opens up and allows communal relationships to flourish, the "me" and "you" separate in order for 
each to become, to feel life as something real and worth living. In this sense the element of personal and social identity arise (see Giddens 1990, 96). Likewise, through our discursive interchanges, our relatedness and separateness dialectically interweave so that the existential "I" and "You" can emerge and converge leading into a new "we" (see Frederickson 2005, 81). It is the "we" that we can integrate sense of individuality and at the same time sociality. For it is only in respecting my own integrity and uniqueness as an individual that I may be able to form a concept of who I am. Conversely, it is also respecting the otherness of the other that my own community flourishes (see Fromm, 1957, 46). Thus, personal identity, which is the natural experience of "I-am-I" as a separate entity, is seen here as a part of social intimacy. This means that our personal identity remains intact but our social identity is a continuous discovery of who we are in the midst of social reality around us (see Donskis 2009, 8). After all, human nature, says Fromm $(1947,22)$, is not fixed; and culture thus is not to be explained as the result of fixed human instincts, nor is culture a fixed factor to which human nature adapts itself passively and completely. He reiterates this beautifully in To Have or To Be $(1997,53)$, where he declares that relatedness and human rootedness are activities that must come within us and must generate a rebirth which is always bringing forth something productive, which flows and flows in itself and beyond itself.

\section{CONCLUSION}

Identity is therefore a passport to a self-legitimizing narrative of my community, group, or nation (Donskis 2009, 10). Being identified to a particular a group or community is one's existential foundation. It is the basis for legitimacy claims, moral claims and political claims. In spite of the insecurities and anxieties in a highly competitive world, identity relation allows the individual to legitimate his own self (see Dunn 1998, 24). Identity relations contributes in some ways to that ontological security in so far that it sustains trust in the continuity of the past, present, and future and connects such trust into routinized social practices (Giddens 1990, 105). However, it is worthwhile to tell that through those intimacies, we develop and create our life in order to be born and reborn into something new; and accordingly, this rebirth will allow us to live our lives fully. After all, Fromm $(1947,23)$ says, "Man is not a blank sheet of paper on which culture can write its text; he is an entity charged with energy and structured in specific ways, which, while adapting itself, reacts in specific and ascertainable ways to external conditions." Here, we become the actors and creators of our own destiny.

\section{RE F E R E N C E S}

Bauman, Zygmunt. 2001. Community. London: Polity Press.

Berman, Marshall. 1982. All that is solid melts into air: The experience of modernity.

New York: Penguin Books.

Biancoli, Romano. 2006. The search for identity in the being mode. Fromm Forum: Annual Publication of the International Erich Fromm Society. Vol.10 English edition: 23-30. 
Biancoli, Romano. 2002. Individuation in analytic relatedness. Contemporary Psychoanalysis, 38:589-612.

Biancoli, Romano. 1995. Center-to-center' relatedness between analyst and patient. International Forum of Psychoanalysis, 4, (2): 105-110.

Bischof, Ledford J. 1964. Interpreting personality theories. ${ }^{\text {nd }}$ Ed. New York: Harper and Row Publishers.

Burston, Daniel. 2006. Psychotherapy and postmodernism: Agency, authenticity, and alienation in Contemporary Therapeutic Discourse. Psychotherapy and Politics International, 4 (2) 119-130.

Davis, Harry. 2003. Erich Fromm and postmodernism. The Psychoanalytic Review, 90 (6): 839-853.

Donskis, Leonidas. 2009. Troubled identity in the modern world. New York: Palgrave Macmillan.

Dunn, Robert. 1998. Identity crisis: A social critique of postmodernity. London: Minnesota.

Fromm, Erich. 1941. Fear of freedom. U.S: Farrar \& Rinehart.

Fromm,Erich.1944.Individual and social origin of neurosis. American SociologicalReview. 9 (No. 4): 231-237. https://www.marxists.org/archive/fromm/ works/1944/neurosis.htm. Accessed: November 8, 2013'

Fromm, Erich. 1947. Man for himself: An inquiry into the psychology of ethics. New York: Holt Paperbacks.

Fromm, Erich. 1955. The sane society. Canada: Holt, Rinehart, and Winston.

Fromm, Erich.1957. The art of loving. London: Thorson Publisher.

Fromm, Erich. 1959. On the Limitations and Dangers of Psychology. In Religion and culture. Essays in honor of Paul Tillich. Edited by W. Leibrecht. New York: Harper and Row.

Fromm, Erich.1964. The heart of man: Its genius for good and evil. New York: Harper and Row.

Fromm, Erich. 1997. To have or to be. London: Continuum.

Fromm, Erich. 1994. Selfishness and self-love. International Erich Fromm Society. 5: 173-197.

Fromm, Erich. 1977. My own concept of man. Fromm Forum (English Edition - ISBN 1437-1189), 17: 1-8.

Fromm, Erich. 1992. Man's impulse structure and its relation to culture. In Beyond Freud: Fromm Individual to social psychology. Edited and with Foreword by Rainer Funk. New York: American Health Foundation: 17-74 York: American Mental Health Foundation: 17-74.

Frederickson, Jon. 2005. The problem of relationality. Relational and intersubjective perspectives in psychoanalysis: A critique. New York: Jason Aronson.

Frosh, Stephen. 1991. Identity crisis: Modernity, psychoanalysis, and the self. New York: Pelgrave McMillan.

Frie, Roger. 2003. Erich Fromm and contemporary psychoanalysis: From modernism to postmodernism. The Psychoanalytic Review 90 (6): 855-868. 
Funk, Rainer. 1982. Courage to be human. New York: Continuum.

Funk, Rainier. 2010. Living by the manual: Ego oriented social character - pathogenic effects of globalization. International Forum of Psychoanalysis 19 (2): 84-91.

Funk, Rainier. 2013. The striving for unboundedness and its impact on psychoanalytic treatment. Fromm Forum English Edition), Vol. 17: 22-28.

Giddens, Anthony. 1990. The Consequences of modernity. UK: Polity Press.

Gubrium, Jaber F. 1995. Individual agency, the ordinary, and the postmodern Life. The Sociological Quarterly 36 (3): 555-570.

Hewitt, John P. 1989. Dilemmas of the American self. Philadelphia: Temple University Press.

Hsueh-Hua Chen, Vivian. 2014. Cultural identity. Key concepts in intercultural dialogue, No. 22, 2014. 1. http://centerforinterculturaldialogue.org/2014/07/07/key-concept-22cultural-identity-by-vivian-hsueh-hua-chen/. Accessed: October 14, 2017

Lankshear, Colin. 2003. On having and being: The humanism of Erich Fromm. Counterpoints, Vol.168: 54-66.

Lasch, Christopher. 1979. The culture of narcissism. New York: W.W. Norton and Company.

Mclaughlin, Neil. 2001. Optimal marginality: Innovation and orthodoxy. Fromm's Revision of Psychoanalysis. Sociological Quarterly. 42 (2): 271-288.

Mahler, Margaret, Pine, Fred, Bergman, Anni. 1975. The psychological birth of the human infant: Symbiosis and individuation. London: Hutchinson.

Meyer, Gerd. 2006. Leading a productive life in postmodern society? Conditions, opportunities, empirical findings. Fromm Forum (English Edition) Vol. $10: 62-72$.

Peters, Mathijs. 2016. Erich Fromm on resonance and alienation. In Fromm Forum (English Edition), Vol. 20: 24-34.

Noon, Jeff. 2003. Critical humanism and the politics of difference. London: McGillQueen's University Press.

Pacquing, Ian Raymond B. 2013. The power of man in Fromm's humanistic ethics. Kritike $7(2): 33-49$.

Pacquing, Ian Raymond B. 2017. Neoliberalism and our precarious culture. Kritike, 11 (1):277-292.

Panfilova, Tatiana. 2010. Identity as a problem today. Fromm Forum (English Edition) 14:43-51.

Risari, Giorgio. 2017. Humanistic conscience: Identity, 'productivity' and Biophilia in Erich Fromm. In Death and the Love for Life in Psychoanalysis.In Memoriam Romano Biancoli, Edited by M. Bacciagaluppi and G. Signorini. International Erich Fromm Society.

Ritzer, George. 2002. Mcdonaldization: The reader. London: Fine Forge Press.

Zima, Peter. 2015. Subjectivity and identity: Between modernity and post modernity. London: Bloomsbury Academic.

Submitted: 27 February 2019; revised: 25 November 2019.

Philosophia: International Journal of Philosophy

Vol. 21, No. 1, January 2020

ISSN 2244-1875 